\title{
Slips of the Tongue and What to Do About Them
}

COMMUNICATION CORNER NO. 43

\author{
by Philip Yaffe
}

\section{Editor's Introduction}

Each "Communication Corner" essay is self-contained; however, they build on each other. For best results, before reading this essay and doing the exercise, go to the first essay "How an Ugly Duckling Became a Swan," then read each succeeding essay.

One of the most dreaded hobgoblins of public speaking is the pervasive fear that you will say something you didn't really mean to say. This is indeed a problem, but perhaps much less so than you might imagine. 


\title{
Slips of the Tongue and What to Do About Them
}

COMMUNICATION CORNER NO. 43

\author{
by Philip Yaffe
}

Recently I have noticed a strange phenomenon. Actually, probably not strange. It had almost certainly been going on for a long time and I had just never noticed it.

I am talking about how people in the public eye (and ear) sometimes tangle their words and say something that may be exactly the opposite of what they want to say. However, in every case I have noticed, they plow right on as if nothing had happened.

Why? Because for them (and for most of their audience), nothing had happened. In most cases, people know what they meant to say, even if that isn't what they said.

It is important to understand this about public speaking. An occasional slip of the tongue is normal and quickly forgiven by the audience-if they even notice it. Even when they do, most people most of the time will recognize a slip of the tongue for what it is and realize that what you meant to say is not what you did say. So they excuse it. And you simply move on as if it hadn't happened.

In a recent example, a high-level public health official was discussing the progress being made toward developing a safe and effective COVID-19 vaccine. He said, "It is imperative that the virus be released to the public as soon as possible." Yes, he actually did say "virus" rather than "vaccine." I don't think he noticed it, as did hardly anyone else. However, it wouldn't have mattered because everyone listening to him would have known that he didn't mean virus but vaccine. Thus, no harm done. So the speaker simply moved on.

In another example, I heard someone talking about the cost of an important piece of medical diagnostic equipment. He put the price at $\$ 280$ when he meant to say $\$ 280,000$. And again it wouldn't have mattered whether anyone noticed the stumble because they would have recognized he meant the higher (much higher) figure. And so it goes.

Public speakers reading a speech that has been carefully prepared in advance hardly ever make such errors. However, if you are speaking extemporaneously ("off the cuff") such as during a conversation, a meeting, an interview, etc., such flubs are inevitable. Fretting over this inevitability can seriously damage your ability to express yourself. So don't become rattled. If it 
is important to correct the error (assuming you even notice it), then do so. Otherwise, just move on.

For fun, here are a few notable examples of such innocuous flubs by some very notable people.

Once while giving a public speech, Ronald Reagan, 40th President of the United States, was trying to recall an apposite quotation of John Adams, 2nd President of the United States. Adams had said, "Facts are stubborn things." Reagan slipped and said, "Facts are stupid things."

Mayor Richard J. Daley was the reigning political leader of Chicago during the turbulent 1960s. The Democratic National Convention was held in Chicago in August 1968. However, with the nation divided by the Vietnam War, and the recent assassinations of Martin Luther King, Jr. and Robert Kennedy fueling outrage, the city became a battleground for protests. When confrontations between protesters and police turned violent, Daley made an unfortunate (and certainly unintended) comment that reflected the opinion of many people: "The police are not here to create disorder; they're here to preserve disorder."

Even President Barack Obama, who is the epitome of a calm, cool, collected speaker, has made a few notable flubs. For example:

- "The Middle East is obviously an issue that has plagued the region for centuries."

- "The reforms we seek would bring greater competition, choice, savings, and inefficiencies to our health care system."

- "We continue to ramp up our training and support of local forces that are fighting ISIL on the ground. As I've said before, this aspect of our strategy was moving too slowly. But the fall of Ramadi has galvanized the Iraqi government. So, with the additional steps I ordered last month, we're speeding up training of ISIL forces."

- "Let me introduce to you the next President-the next Vice President of the United States of America, Joe Biden."

And indeed, what about Joe Biden?

Throughout his career, Biden has carried the unenviable label of "gaffe machine," i.e. he makes oral errors. However, two things need to be said about this. First, his gaffes are probably fewer and farther between than he is given blame for. Second, he recognizes his gaffes and apologizes for them when they are brought to his attention.

Donald Trump, his direct nemesis during the 2020 presidential election campaign, also makes enormous gaffes, but is less likely to recognize them or apologize for them when they are brought to his attention. Sometimes he even doubles down.

For example, in 2019 President Trump said his father emigrated to the United States from a lovely little town in Germany. What he should have said was that his grandfather emigrated to the 
United States from a lovely little town in Germany; his father was born and raised in New York. Nevertheless, Trump made the gaffe at least twice (and maybe as many as four times) and never corrected it.

A more recent slip of the tongue occurred in August 2020 when he informed the world that the Spanish flu pandemic started in 1917 (it was actually 1918) and probably contributed to ending the Second World War (1939-1945) rather than the First World War (1914-1919). He also made the misstatement that the Continental Army "took over the airports" from the British during the American Revolution (War for Independence). This epoch-making conflict took place from 17751783, well over a century before the airplane was invented by the Wright Brothers in 1903.

So if a slip of the tongue happens to you (and be assured that it will, it happens to everyone), what should you do about it? Here are a few suggestions.

- You do nothing. This is probably because you won't even notice that it happened, so there is nothing you can do. Just keep talking.

- Gauge the audience's reaction. If there appears to be little or no reaction, again do nothing. Keep on talking.

- Recognize the error. If the audience does seem to be reacting, smile and recognize the error. "Oops, of course what I meant to say ...."

- Correct the error. If you have any doubts that the audience may have taken your misstep seriously, "Of course that would be ridiculous. What I meant to say was . ..."

But in any case, don't panic. Because in most cases, it won't really matter.

The American philosopher and scientist Benjamin Franklin once opined, "A slip of the foot you may soon recover, but a slip of the tongue you may never get over." I think this may have been an overstatement.

\section{ABOUT THE AUTHOR}

Philip Yaffe was born in Boston, Massachusetts, in 1942 and grew up in Los Angeles, where he graduated from the University of California with a degree in mathematics and physics. In his senior year, he was also editor-in-chief of the Daily Bruin, UCLA's daily student newspaper. He has more than 40 years of experience in journalism and international marketing communication. At various points in his career, he has been a teacher of journalism, a reporter/feature writer with The Wall Street Journal, an account executive with a major international press relations agency, European marketing communication director with two major international companies, and a founding partner of a specialized marketing communication agency in Brussels, Belgium, 
where he has lived since 1974 . He is the author of more than 30 books, which can be found easily in Amazon Kindle.

DOI: $10.1145 / 3519351$ 